\title{
The pig's doom: Animal butchery, gender relations, and a new solution for Durbam Proverb 10
}

\author{
Erik Wade \\ Universität Bonn
}

The Old English and Latin Durham Proverbs are famously obscure. Durham Proverb 10 describes a man sitting on a pig; the man jokes that what happens next is up to the pig. Scholars have read this as a possible marital joke, since the man is called a ceorl or maritus 'husband', yet this article suggests that the context is that of pig butchery. Medieval art frequently shows pigs being butchered by a man sitting on top of them to hold them down. Moreover, they often show the butchery performed by a man and a woman, suggesting that this proverb was a reference to an activity that a couple performed together, rather than a sexist commentary on marriage.

Keywords: Durham Proverbs; gender; Old English; pigs

The Durham Proverbs are a set of forty-six Latin proverbs, each followed by an Old English version. They are preserved in an eleventh-century manuscript, but the dating of their composition is uncertain (Arngart 1956: 3, Arngart 1981: 289). Scholars have debated both their meaning and whether the Latin or Old English came first (Arngart 1956: 6). These proverbs have received scant attention, and many of their meanings remain deeply enigmatic. One such troublesome proverb is Durham Proverb 10:

Nunc in iudicio porci dixit maritus sedens in apro.

$\mathrm{Nu}$ hit ys on swines dome, cwæð se ceorl sæt on eoferes hricge.

[“Now it's up to the pig's judgment!" said the churl who sat on the boar's back.] ${ }^{1}$

\footnotetext{
${ }^{1}$ Latin and Old English quoted from Arngart (1981: 292). Translation mine, from the Old English.
}

Erik Wade, Selim25 (2020): 187-192.

ISSN 1132-631X / DOI: https://doi.org/10.17811/selim.25.2020.187-192 
A remarkably early example of the Middle English "quoth he who" proverb form, these cryptic lines have never been properly explained (Arngart 1981: 289). In 1948, the Oxford Dictionary of English Proverbs claimed this proverb exemplified "the freakish humour so often expressed in the gargoyles and grotesques of medieval sculpture and illumination" (quoted in Arngart 1981: 296). Since then, Proverb 10 has been afforded only a few scholarly guesses. Richard Marsden proposed that it may be a "joke about the perils of marriage", since ceorl can mean both 'peasant/yeoman' and 'husband', while the Latin maritus means 'husband' (2004: 306, n.10). Olaf Arngart (1956: 5) simply remarked that the proverb reflects a "coarser strain" of humor and also translates ceorl as 'husband', suggesting that he may even see it as a sexual joke.

I suggest that the image of riding a pig comes from a less metaphorical activity: a butchering one. Post-Conquest manuscript art has many examples of this theme: a man astride a pig, feet usually planted on the ground, either cutting its throat or stabbing it (see Figure 1). ${ }^{2}$ This art appears particularly in Books of Hours to mark December, the month when pigs were butchered. Examples of this appear across manuscripts, mostly with the butcher actually astride the pig. ${ }^{3}$ Other manuscripts have the butcher standing with one foot planted on the pig as the butcher swings an ax (as in Bodleian Library MS. Liturg. 396, fol. 006r) or standing just behind the pig, with feet planted on either side, as they prepare to butcher it (as in Bodleian Library MS. Douce 24, folio 006r).

\footnotetext{
${ }^{2}$ Even Marsden (2004: 306, n.10) notes that two thirteenth-century stone carvings in the chapter house of York Minster "depict a man precarious astride a pig".

${ }^{3}$ See Morgan Library MS M189, folio 006v; Morgan Library MS M511, folio 006v; Morgan Library MS M174, folio 012r; Morgan Library MS M197, folio 006r. See also Bodleian Library MS. Auct. D. 4. 2, folio 009v; Bodleian Library MS. Douce 12, folios 012v-013r; Bodleian Library MS. Douce 5, folio 006v-007r. Others can be found in other major collections, such as the farmer standing astride a pig and swinging an ax in MS 76 F 13 (folio 12v) from the Koninklijke Bibliotheek collection.
} 


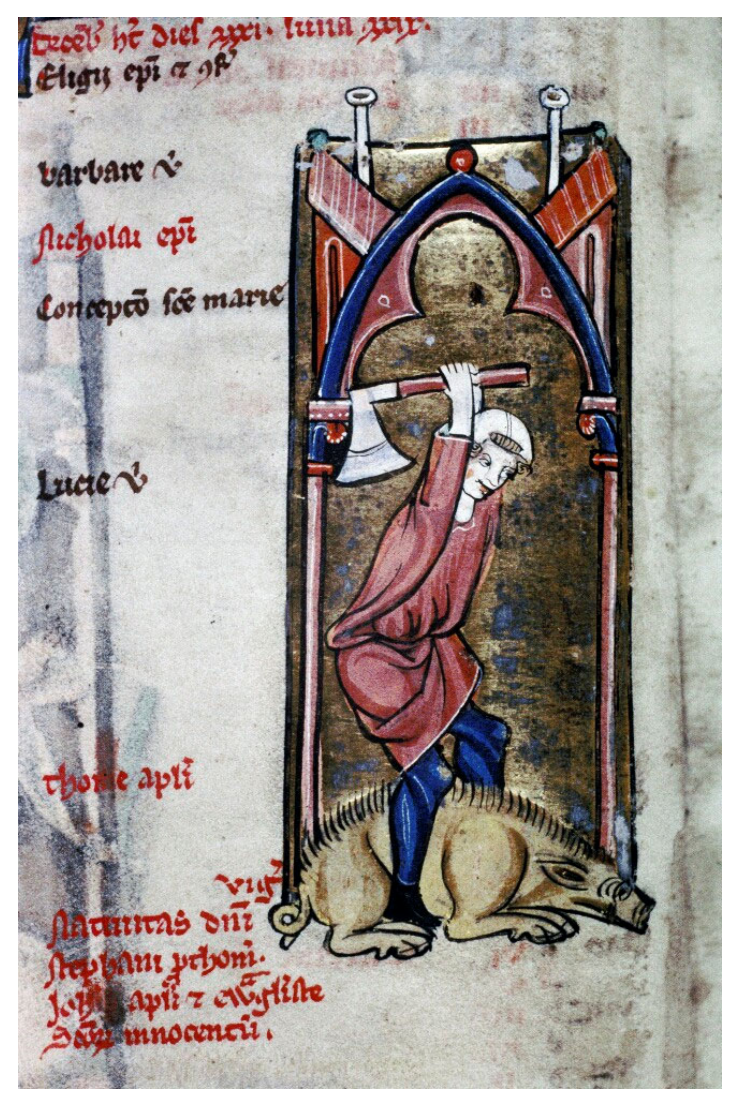

Figure 1. Bodleian Library MS. Auct. D. 4. 2, folio 009v. Photo: Bodleian Libraries, University of Oxford 2020.

https://digital.bodleian.ox.ac.uk/inquire/p/79410aaa-310d-49ec-a39e-4a8e97e0436f

Certainly, there are other contexts for figures astride pigs, but these are the exception to the butchering trope. A monkey dressed in bright colored clothes rides a pig backwards in MS M282 (folio 077r) from the Morgan Library, suggesting a theme of anarchy. A personification of Gluttony rides a pig in MS M1001 (folio 094r) from the Morgan Library. A barefoot man in colorful clothes rides a pig in the margins of Bodleian Library MS. Laud Misc. 302 (folio 123r). The majority of depictions, however, are of butchering.

Pig-keeping was one of the earliest forms of animal husbandry in medieval England. Starting in the fifth and sixth centuries, archaeological evidence 
indicates an increase in animal husbandry in East Anglia, including "an increasing proportion of pigs and sheep, in contrast to more specialized meat cattle production at earlier sites in the region" (Lewit 2009: 80). It is possible that, after this early period of colonization, pig-keeping decreased, while cattle and sheep farming increased (Crabtree 1989: 205). Nonetheless, medieval art demonstrates that pig keeping never went out of style.

So, if the proverb refers to pig butchering, what does the line about it being "on swines dome" ['in the swine's judgment'] mean? Two possible solutions present themselves: firstly, there may be a play on the word dome ['doom/judgment/sentence']. In other words, the lines could mean it is now the pig's doom/sentence, not that is in the pig's judgment what happens next. The primary meaning of dom is not 'judgment' as in 'choice' but 'judgment' as in 'judicial sentence' (Bosworth 1898: 207). Certainly, "the pig's sentence" would be an unusual reading of the construction, as the genitive in most comparable sentences almost always refers to the person passing the sentence (i.e. 'the lord's doom', etc.). But the word-play would be audible.

The second solution is that "on swines dome" refers to the pig's choice, and that this refers to the unpredictability of a semi-domesticated, strong animal being sat upon and held down to be slaughtered. This solution accepts the usual reading of "in the swine's choice", but provides the historical context in which it would be most easily understood: the barnyard in wintertime, when farmers wrestled with pigs unwilling to die and pinned them with their thighs and their own weight. Much medieval art shows the butcher clearly struggling to restrain or pin the pig. ${ }^{4}$ Karl Steel (2011: 181-184) notes medieval pigs were only partially domesticated; they "led quasi-feral lives for most of the year" and records describe their frequent violence, as they often killed or injured people. Durham Proverb 10 seems like an account of pigs' unpredictability and potential struggles when they were slaughtered in the winter. One can easily imagine such a colloquial saying producing knowing chuckles.

As a metaphor, the difficulty of restraining a pig for slaughter would be versatile and could easily be applied for many other situations, including possibly the marital situations suggested by other scholars. The connotations of the slaughter season would lend any marital version of this saying a certain grim violence.

\footnotetext{
${ }^{4}$ See, for example, Morgan Library MS M189, folio 006v; Morgan Library MS M511, folio 006v; and Morgan Library MS M174, folio 012r.
} 
Nonetheless, the context of the slaughter means that the proverb likely was not a marital joke but a reflection that both men and women participated in butchering. Many artistic representations show a man straddling the pig to kill it, and a woman holding out a basin to catch the blood jetting from the pig's neck. ${ }^{5}$ Such scenes suggest that the word ceorl or maritus mean 'husband' but do not necessarily imply that this is a sexist riddle where the wife plays the part of a troublesome swine. It may reflect the simple fact that farming couples often did the butchering: the husband astride the pig, and the wife holding out a pan for the blood (see Figure 2). Seen in this light, Durham Proverb 10 need not be a commentary on marriage at all, but instead the sort of joke a husband might make to his waiting wife as he seated himself on the pig and raised the knife.

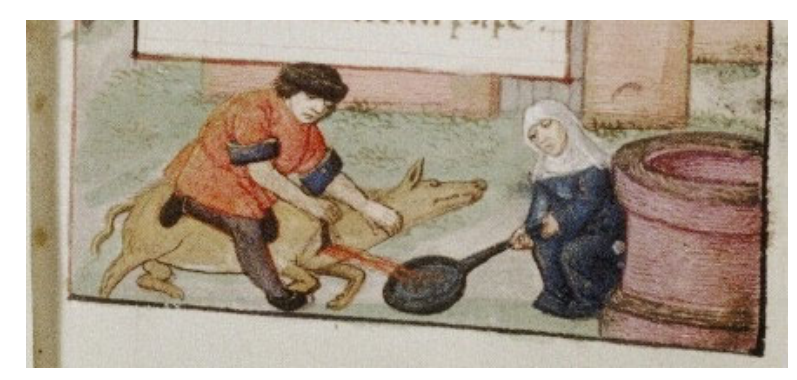

Figure 2. Bodleian Library MS. Douce 12, folio 013r. Photo: Bodleian Libraries, University of Oxford 2020.

https://digital.bodleian.ox.ac.uk/inquire/p/b71476c7-ba67-40e5-b9ca-

$7 \mathrm{~cd} 5230 \mathrm{cc} 024$

\section{References}

Arnart, O. 1956: The Durbam Proverbs. Lund, C. W. K. Leerup.

Arnggart, O. 1981: The Durham Proverbs. Speculum 56.2: 288-300.

Bosworth, J. 1898: DÓM. In T. N. Toller ed. An Anglo-Saxon Dictionary: Based on the Manuscript Collections of the Late Joseph Bosworth. Oxford, Clarendon Press: 207.

Crabtree, J. 1989: Sheep, Horses, Swine, and Kine: A Zooarchaeological Perspective on the Anglo-Saxon Settlement of England. Journal of Field Archaeology 16.2: 205-213.

\footnotetext{
${ }^{5}$ Examples include Bodleian Library MS. Douce 12, folios 012v-013r; Morgan Library MS Morgan M64, folio 12r; and Morgan Library MS M174, folio 012r.
} 
Lewit, T. 2009: Pigs, Presses and Pastoralism: Farming in the Fifth to Sixth Centuries AD. Early Medieval Europe 17.1: 77-91.

Marsden, R. 2004: The Cambridge Old English Reader. Cambridge, Cambridge University Press.

Steel, K. 2011: How to Make a Human: Animals \& Violence in the Middle Ages. Columbus $(\mathrm{OH})$, Ohio State University Press.

\author{
Author's address \\ Department of English American and Celtic Studies \\ Universität Bonn \\ Regina-Pacis-Weg 5 \\ 53113 Bonn \\ Germany \\ e-mail: ewade@uni-bonn.de
}

received: 5 June 2020

revised version accepted: 28 July 2020 